\title{
Specjalne strefy ekonomiczne i strefy przemysłowe w ksztaltowaniu rozwoju gospodarczego regionów na przykładzie Polski i Czech
}

Transformacja systemu społeczno-gospodarczego w krajach Europy Środkowej i Wschodniej, która nastąpiła na przełomie lat 80. i 90., przełożyła się na zmiany w funkcjonowaniu gospodarki, w tym także na przestrzenną organizację produkcji. Nastąpił w tym okresie wzrost zróżnicowań przestrzennych zarówno w skali lokalnej, jak i regionalnej. Struktura przestrzeni gospodarczej kształtowana w warunkach gospodarki centralnie sterowanej nie uległa szybkim i radykalnym zmianom, a w polityce gospodarczej nie było miejsca dla polityki regionalnej (Kukliński 1991; Bagdziński, Maik 1994). Procesy gospodarcze zainicjowane po 1989 r. nasiliły zjawisko powstawania przestrzennych skupień przedsiębiorstw i przyczyniły się do szybkiego rozwoju gospodarczego pewnych obszarów, równocześnie na wielu terenach nastąpiła stagnacja bądź nawet recesja związana z upadkiem podmiotów gospodarczych stanowiących bazę ekonomiczną miast i regionów.

Po 1990 r., gdy rozwój regionalny i lokalny regulowany jest głównie przez mechanizmy rynkowe, ważna wydaje się identyfikacja obszarów stagnujących, na terenie których nie rozwijają się nowe formy działalności gospodarczej. Właściwa diagnoza przyczyn tego zjawiska pozwala na podjęcie działań mających na celu zwiększenie atrakcyjności tych obszarów dla potrzeb nowych inwestorów. Jest to szczególnie ważne na obszarach cechujących się monofunkcyjną bazą ekonomiczną związaną z rozwojem dużych kombinatów przemysłowych. Mieszkańcy takich obszarów cechują się bowiem niskim poziomem przedsiębiorczości, co powoduje, iż dalszy rozwój tych regionów jest możliwy tylko poprzez pozyskanie odpowiednich inwestorów zewnętrznych. Poza tym duże przedsiębiorstwa o funkcjach egzogenicznych, a do takich należą firmy przemysłowe, generują rozwój gospodarczy regionu poprzez efekty mnożnikowe, związane z popytem zaopatrzeniowym na dostawy surowców, półproduktów oraz usług, a także dzięki popytowi konsumpcyjnemu, który jest generowany poprzez pracowników tych firm.

Jednym ze sposobów aktywizacji gospodarczej regionów jest koncepcja tworzenia określonych przywilejów dla firm działających na obszarach, których rozwój chcemy wspierać. W Polsce powstała idea tworzenia specjalnych stref ekonomicznych, która w pierwotnych założeniach miała na celu wspieranie rozwoju gospodarczego takich obszarów poprzez przyciąganie na ich tereny dużych przedsiębiorstw przemysłowych (Kryńska 2000). Pierwotna koncepcja stref wraz z ich rozwojem ewoluowała, tworząc obecnie narzędzie przyczyniające się do wzrostu konkurencyjności przedsiębiorstw (Domański, Gwosdz 2005). 
Celem autorów niniejszego opracowania jest pokazanie, jak zmieniające się podejście do specjalnych stref ekonomicznych w Polsce wpływało na konkurencyjność regionów Polski w skali wewnętrznej jak i zewnętrznej. W przypadku określenia uwarunkowań zewnętrznych dokonano analizy porównawczej konkurencyjności regionów Polski na tle Czech.

\section{CELE FunKCJONOWANIA SPECJALNYCH STREF EKONOMICZNYCH}

Idea tworzenia obszarów uprzywilejowanych gospodarczo na określonych terytoriach nie jest koncepcją nową (Guangwen 2003). Podobieństwa możemy się dopatrywać w przywilejach handlowych przyznawanych niektórym miastom już od czasów rzymskich (Delos w Grecji). Rozwój tej koncepcji miał miejsce w średniowieczu, np. miasta ligi hanzeatyckiej czy przyznawane prawo składu. M. Guangwen (2003) wskazuje, że idea uprzywilejowanych obszarów ekonomicznych przeszła długą ewolucję: od stref opartych na handlu (popularne od co najmniej XVI w.), poprzez strefy mieszane przemysłowo-usługowe (od 1940 r.), parki przemysłowo-naukowe (od 1970 r.) i strefy transgraniczne (od 1990 r.). Na obszarze Polski koncepcja stref ekonomicznych pojawiła się w 1993 r., jej efektem była utworzona w 1995 r. pierwsza polska SSE w Mielcu. Założenia były wzorowane na strefie utworzonej na terenie irlandzkiego miasta Shannon (1958 r.), która to odniosła ogromny sukces. Istniejące współcześnie różnego rodzaju wolne obszary celne, strefy wolnego handlu, strefy produkcji na eksport (EPZ) łączy wspólna cecha, jaką są sprzyjające inwestorom regulacje ułatwiające pozyskanie inwestorów, poprzez co promują rozwój gospodarczy regionów, na terenie których zostały utworzone. Głównymi oczekiwanymi efektami ich powstania jest tworzenie nowych miejsc pracy, zwłaszcza na obszarach depresji gospodarczej, zwiększenie powiązań gospodarki krajowej z zagranicą (promocja eksportu) oraz poprawa konkurencyjności gospodarki poprzez transfer technologii i wzrost kwalifikacji pracowników (Gwosdz i in. 2005).

Specjalne strefy ekonomiczne są więc narzędziem polityki regionalnej, ich celem jest bowiem rozwój określonych regionów. Pierwotnym założeniem tworzonych w Polsce stref było przyciagnięcie inwestorów na obszary znajdujące się poza terenami opłacalności prowadzenia danej działalności albo uważanymi za takie przez przedsiębiorców (ryc. 1). Główną zachętą dla nowych inwestycji było oferowanie zwolnień podatkowych dla przedsiębiorstw lokalizujących swoje zakłady na obszarach stref.

Idea specjalnych stref ekonomicznych jest także przedmiotem krytyki, gdyż poprzez specjalne przywileje preferuje się rozwój jednych obszarów kosztem innych. W skali kraju dochodzi więc do zjawiska substytucji. Kolejnym polem konfliktu jest także wybór miejsc ustanowienia stref. Obszarów peryferyjnych o gorszych warunkach do prowadzenia działalności gospodarczej jest wiele. Duża liczba tworzonych stref powoduje, że efekty ich funkcjonowania są rozmyte, co nie prowadzi do oczekiwanego rozwoju tych regionów. Można postawić także pytanie, na ile powinniśmy dążyć do zwiększania szans rozwoju terytoriów peryferyjnych, co prowadzi do zwiększania się koherencyjności wewnętrznej, a na ile celem polityki gospodarczej powinno być zwiększanie się konkurencyjności globalnej kraju poprzez poprawę atrakcyjności terenów najbardziej predestynowanych do prowadzenia określonych działalności (ryc. 2). Nie ulega bowiem wątpliwości, że tworzenie specjalnych stref ekonomicznych w obszarach takich jak aglomeracja Wrocławia czy Poznania powoduje z jednej strony zwiększenie dysproporcji i marginalizację obszarów peryferyjnych kraju, natomiast z drugiej prowadzi do zwiększenia konkurencyjności Polski na arenie międzynarodowej. 


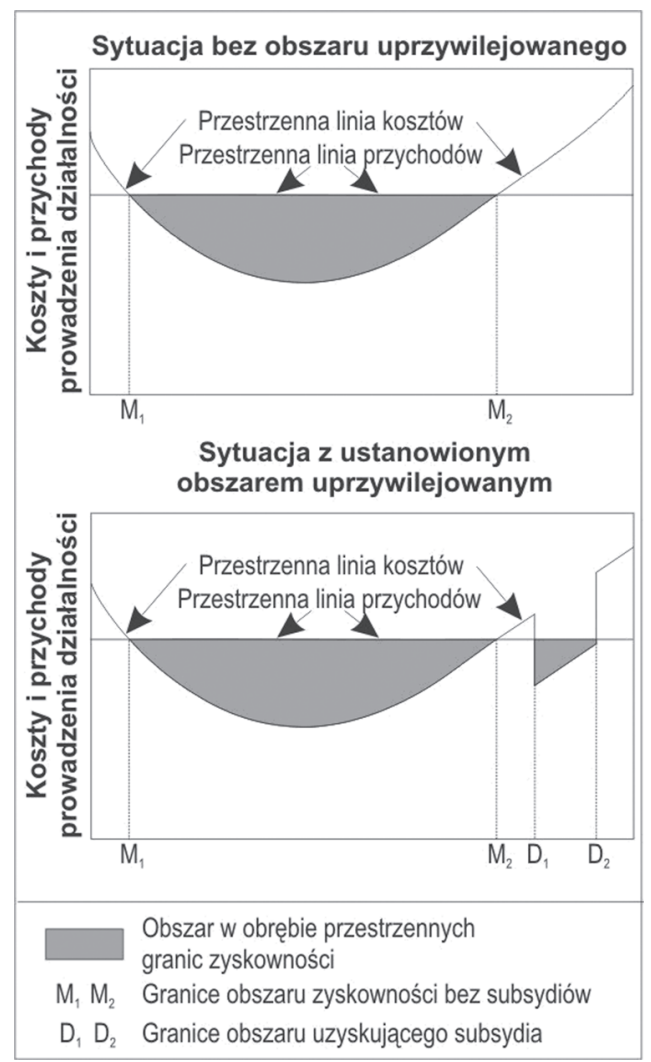

Ryc. 1. Przestrzenne granice zyskowności a istota subsydiów

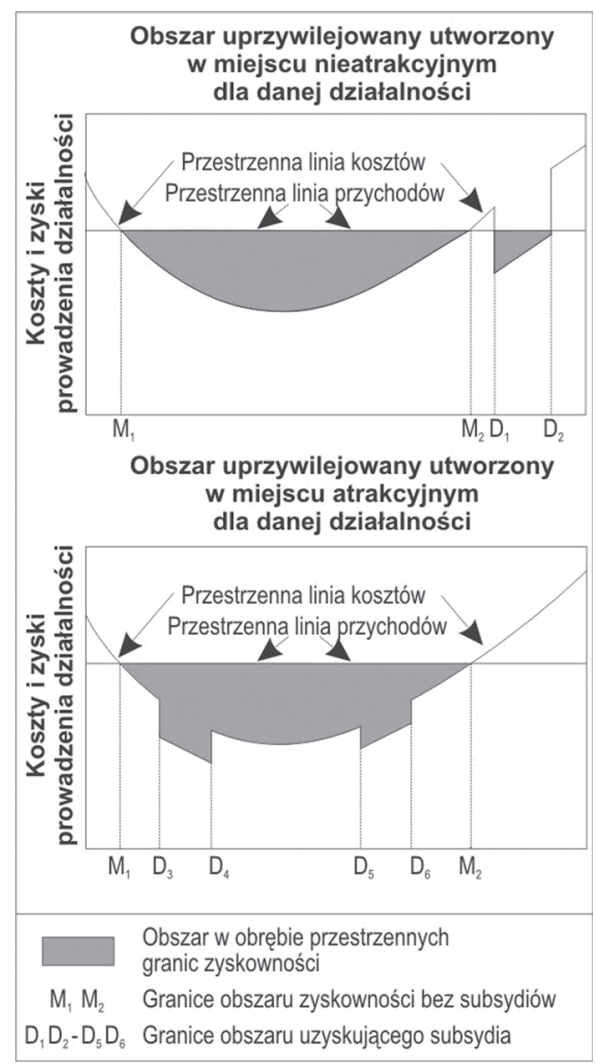

Ryc. 2. Przestrzenne granice zyskowności a lokalizacja obszarów objętych subsydiami

Źródło: za Gwosdz, Huculak, Jarczewski, Wiedermann (2005) na podstawie Smith (1966)

\section{RozMieszCZENIE SSE NA OBSZARZE Polski}

W roku 1995 powstała pierwsza w Polsce specjalna strefa ekonomiczna, która została zlokalizowana na terenie Mielca (SSE Euro-Park Mielec). Ośrodek ten zagrożony był wówczas głęboką depresją gospodarczą związaną z restrukturyzacją przedsiębiorstwa WSK Mielec, które stanowiło podstawę bazy ekonomicznej miasta. W firmie tej przed okresem transformacji ustrojowej pracowało ponad 20 tys. osób, co w zestawieniu z liczbą 68 tys. mieszkańców świadczyło, iż miasto to stanowiło klasyczny przykład ośrodka typu mill town - w takim przypadku ewentualny upadek głównego zakładu produkcyjnego prowadził nieuchronnie do degradacji miasta. Zagrożenie to zaczęto dostrzegać już wcześniej i starano się znaleźć rozwiązanie. W 1993 r. rozpoczęły się prace nad stworzeniem strefy. Jej uruchomienie wiązało się z koniecznością stworzenia nie tylko odpowiednio przygotowanych terenów pod inwestycje, ale także wprowadzenia odpowiednich rozwiązań legislacyjnych. Wzorem rozwiązań dla tworzonej w Mielcu strefy była utworzona w $1958 \mathrm{r}$. irlandzka strefa w Shannon. Ostatecznie mielecką strefę utworzono jesienią 1995 r. 
W zamierzeniu miała ona być strefą pilotażową, jednak zanim rozpoczęła ona działalność gospodarczą, zapowiedziano powołanie kolejnych uprzywilejowanych obszarów (Budzowski, Świętowiec 1997). W 1996 r. ustanowiono katowicką SSE, a jej powstanie związane było z negatywnymi skutkami restrukturyzacji i prywatyzacji, ale także z przebranżowieniem się przedsiębiorstw na obszarze Śląska. Prawie równocześnie z katowicką powstała Suwalska SSE - celem jej założenia była chęć uprzemysłowienia obszarów leżących peryferyjnie względem innych ośrodków przemysłowych. W pierwszej połowie 1997 r. utworzono następne strefy (legnicką, łódzką i wałbrzyską). Kolejne 11 SSE zostało powołanych w końcu 1997 r. przez ustępujący rząd W. Cimoszewicza. W 2000 r. liczba stref sięgnęła 17. Zaledwie jednak sześć z nich stanowiło strefy zwarte, obejmujące swymi granicami jeden kompleks terenów. W 2000 r. funkcjonowało nie 17, a co najmniej 41 oddzielnych obszarów o specjalnym statusie ekonomicznym, a gdyby liczyć wszystkie wydzielone W strefach i podstrefach kompleksy produkcyjne, to liczba ich wzrosła do 68 (Kuliś 2001). W kolejnych latach liczba lokalizacji powiększała się w tempie niemal geometrycznym, aby w końcu 2005 r. osiągnąć wartość 134. (ryc. 1). W międzyczasie podjęto decyzję o likwidacji dwóch stref: częstochowskiej, która obecnie jest częścią podstrefy sosnowiecko-dąbrowskiej w katowickiej SSE; oraz mazowieckiej.

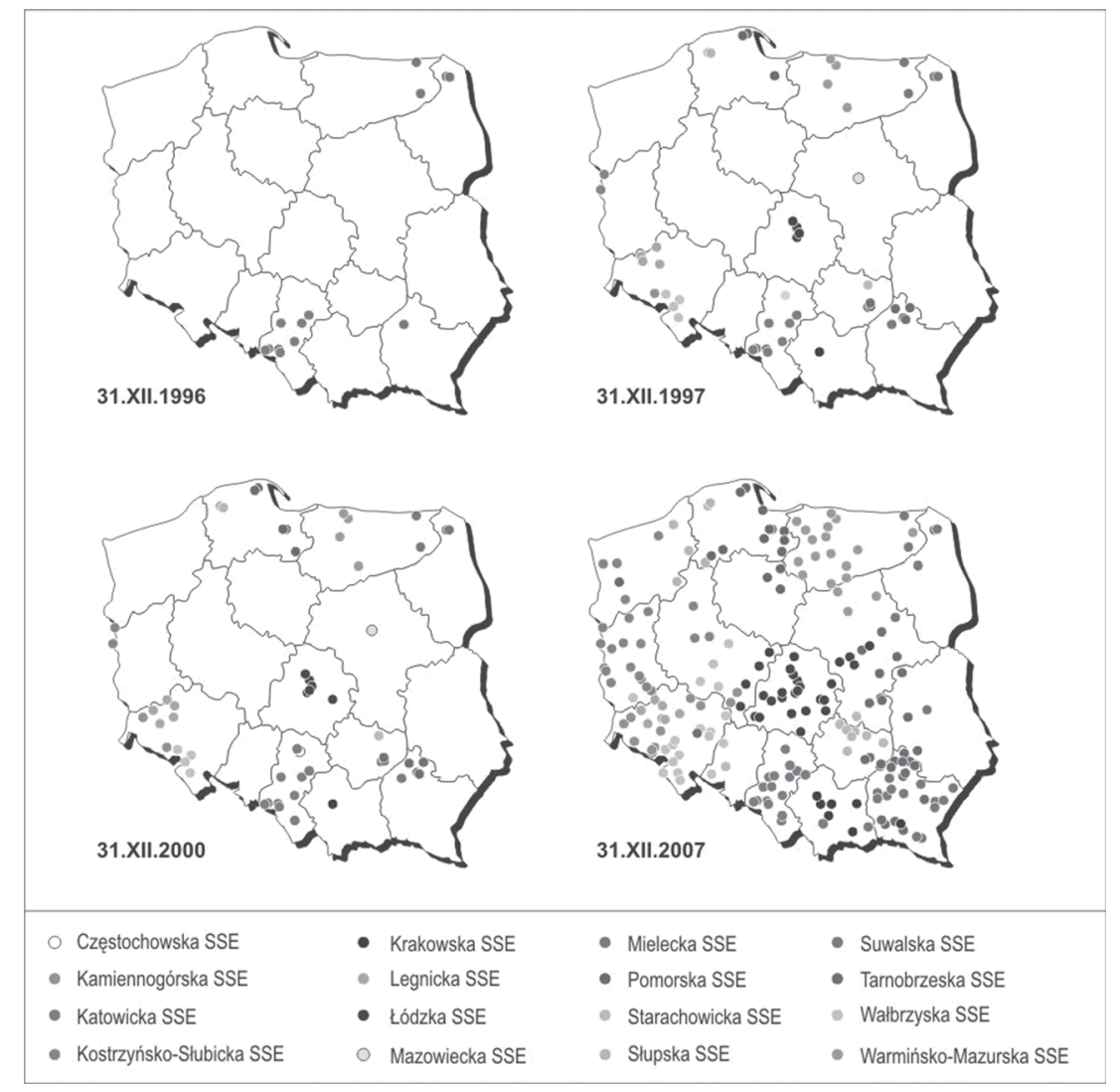

Ryc. 3. Rozmieszczenie specjalnych stref ekonomicznych na obszarze Polski

Źródło: opracowanie własne na podstawie Gwosdz, Huculak, Jarczewski, Wiedermann (2005) 
Jednym z mierników działalności SSE jest liczba miejsc pracy, które generują przedsiębiorstwa. Wśród wszystkich polskich SSE największe efekty w walce z lokalnym bezrobociem wykazały strefy: katowicka - 30522 nowych miejsc pracy i wałbrzyska - 20164 miejsca (tab.1). W wypadku pierwszej najwięcej zatrudnionych jest w przedsiębiorstwach TRW Polska, General Motors Manufacturing Poland oraz Fiat GM Powertrain Poland, natomiast w wałbrzyskiej najwięcej miejsc pracy utworzyły firmy Mahle Polska, Faurecia Wałbrzych, Toyota Motor Manufacturing Poland, Toyota Motor Industries Poland, Electrolux Poland (tab. 1.).

Powstawanie nowych stanowisk pracy jest szczególnie ważne na obszarach, gdzie firmy działające na obszarze strefy aktywizują znaczny odsetek liczby ludności w wieku produkcyjnym. Mielecka SSE odznacza się największym odsetkiem zatrudnionych osób spośród aktywnej zawodowo ludności na lokalnym rynku pracy. W 2005 r. aż 16\% aktywnej zawodowo ludności powiatu pracowało na obszarze strefy. Wskaźnik ten jest zdecydowanie niższy dla pozostałych stref, także dla katowickiej, która zatrudnia do 10\% ludności aktywnych zawodowo zamieszkałych na terenie Śląska (ryc. 4).

Przedsiębiorstwa, które zdecydowały się zlokalizować swoją działalność na terenie SSE, mogły liczyć na całkowite zwolnienie z płacenia podatku dochodowego dla przedsiębiorstw (CIT) przez pierwsze 10 lat swojej działalności, a przez kolejne lata na zwolnienie w wysokości 50\% podatku, którego stawki wynosiły odpowiednio w 1996 r. 40\%, a w 2003 27\% (Ustawa z dnia 20 października 1994 r. o specjalnych strefach ekonomicznych). W późniejszych latach zmieniano wielkość maksymalnej intensywność pomocy publicznej, która od końca 2000 r. wynosiła 50\% poniesionych nakładów inwestycyjnych na większości obszarów kraju, z wyjątkiem następujących powiatów grodzkich: Wrocław, Kraków, Gdańsk, Gdynia i Sopot - 40\%, Warszawa i Poznań - 30\% (Ustawa z dnia 16 listopada 2000 r. o zmianie ustawy o specjalnych strefach ekonomicznych). W 2006 r. w ramach nowych wytycznych Unii Europejskiej zmieniona została mapa pomocy w Polsce na mocy Rozporządzenia Rady Ministrów z dnia 13 października 2006 r. w sprawie ustalenia mapy pomocy regionalnej (Dz. U. Nr 190. poz. 1402). Kilku województwom obniżono maksymalną intensywność pomocy (dolnośląskie, mazowieckie, pomorskie, śląskie, wielkopolskie, zachodniopomorskie), tym samym zwiększając szanse regionów ściany wschodniej na pozyskanie inwestorów.

W Republice Czeskiej strefy ekonomiczne obejmują cały kraj, różna jest jedynie wysokość zwolnień podatkowych. Istnieją tam tzw. strefy przemysłowe. Są to wielohektarowe obszary, najczęściej na peryferiach średnich i dużych miast, często porolnicze, przygotowywane dla inwestorów (działki uzbrojone w media, nierzadko również w infrastrukturę drogową). Ich skupienie występuje głownie na Śląsku Morawskim, ale także w północnej i środkowej części kraju. Najmniejszą liczbę stref przemysłowych zlokalizowano na obszarze miasta Pragi oraz województw: karlowowarskiego, pilznieńskiego i południowoczeskiego. Występuje tu prawidłowość między liczbą SP a wysokością ulg podatkowych - tam gdzie zwolnienia są najmniejsze (Praga 0-10\%, woj. pilznieńskie i południowoczeskie 36\%) występuje niewielka liczba stref (ryc. 5).

O atrakcyjności strefy ekonomicznej dla przyszłego inwestora decyduje wiele czynników, m.in. przygotowanie terenu pod działalność gospodarczą. Szczególnie ważna jest w tym zakresie odpowiednia infrastruktura drogowa. Łatwo zauważyć, że przy obecnej znacznej liczbie SSE w Polsce przedsiębiorcy wybierają najczęściej te, które znajdują się w pobliżu ważnych szlaków komunikacyjnych, zwłaszcza autostrad. Szczególnie boleśnie odczuła tę zależność Mielecka SSE, która poprzez swoje peryferyjne położenie względem 


\begin{tabular}{|c|c|c|c|c|c|c|c|c|}
\hline 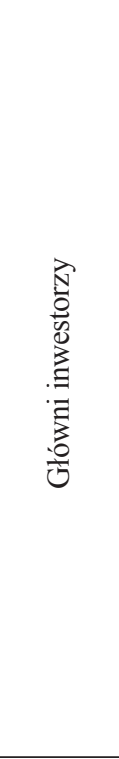 & 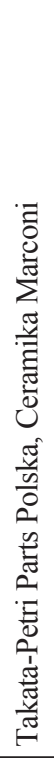 & 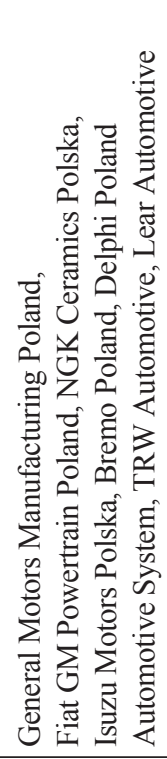 & 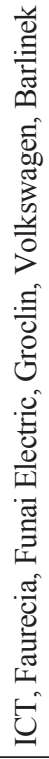 & 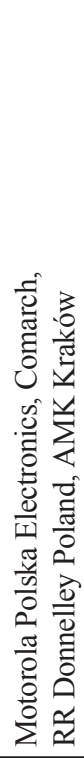 & 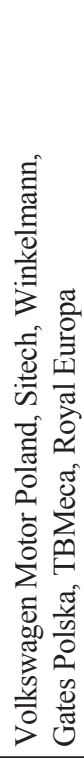 & 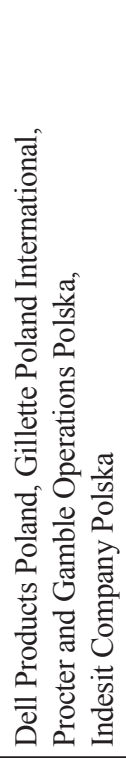 & 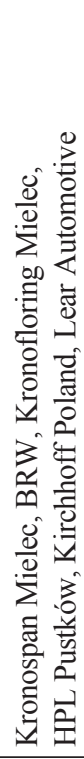 & 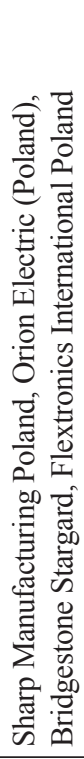 \\
\hline Z & $\begin{array}{l}\infty \\
\stackrel{\circ}{+}\end{array}$ & $\begin{array}{l}\text { त } \\
\text { है } \\
\text { లn }\end{array}$ & $\stackrel{\approx}{n}$ & $\stackrel{m}{m}$ & $\underset{\infty}{\curvearrowright}$ & $\bar{\Xi}$ & $\begin{array}{l}\text { तี } \\
\text { I }\end{array}$ & $\frac{m}{8}$ \\
\hline 䄈 & mి & 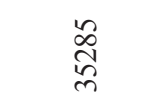 & $\begin{array}{l}\bar{\alpha} \\
\stackrel{0}{1}\end{array}$ & $\begin{array}{l}\text { : } \\
i n\end{array}$ & $\underset{\infty}{\stackrel{d}{\sigma}}$ & 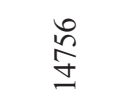 & 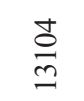 & 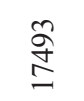 \\
\hline 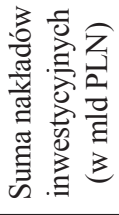 & $\stackrel{0}{\sim}$ & 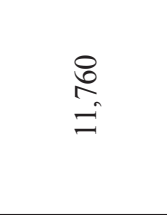 & $\begin{array}{l}\stackrel{0}{5} \\
\stackrel{5}{i}\end{array}$ & $\stackrel{\text { ô }}{-}$ & $\begin{array}{l}\text { ते } \\
\text { r. } \\
\text { m }\end{array}$ & $\begin{array}{l}\infty \\
\infty \\
\text { m. }\end{array}$ & $\underset{m}{\Xi}$ & $\begin{array}{l}\text { aे } \\
\text { i }\end{array}$ \\
\hline 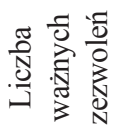 & ले & 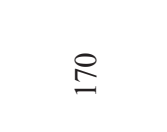 & $\overline{0}$ & $\infty$ & $\hat{n}$ & $\bar{a}$ & $\infty$ & $\sqrt[6]{6}$ \\
\hline 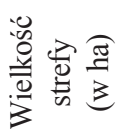 & $\begin{array}{l}n \\
\infty \\
m\end{array}$ & 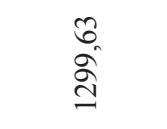 & \begin{tabular}{l}
0 \\
\multirow{2}{*}{} \\
$\tilde{\delta}$
\end{tabular} & $\begin{array}{l}\infty \\
\infty \\
\infty\end{array}$ & $\begin{array}{l}\ddot{\sigma}_{0} \\
\underset{\gamma}{\sigma}\end{array}$ & 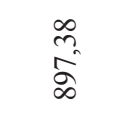 & $\begin{array}{l}\hat{\sigma} \\
\tilde{a} \\
\sigma\end{array}$ & $\begin{array}{l}\nabla_{n} \\
\dot{t} \\
\qquad\end{array}$ \\
\hline 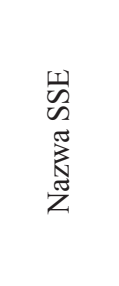 & 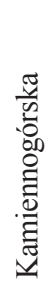 & 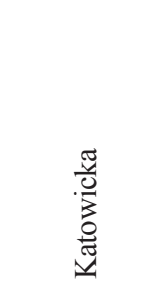 & 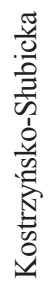 & 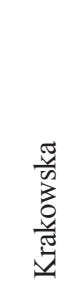 & 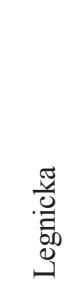 & 岛 & $\begin{array}{l}\frac{\pi}{0} \\
\frac{d}{0} \\
\stackrel{0}{\Sigma}\end{array}$ & 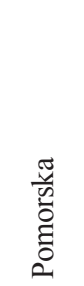 \\
\hline$\stackrel{\dot{1}}{\stackrel{1}{2}}$ & - & $N$ & $n$ & $\nabla$ & in & 0 & $r$ & $\infty$ \\
\hline
\end{tabular}




\begin{tabular}{|c|c|c|c|c|c|c|}
\hline 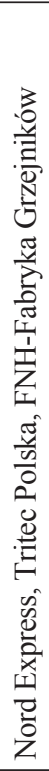 & 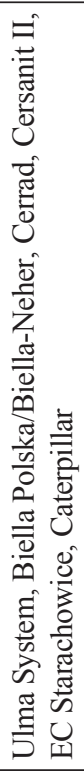 & 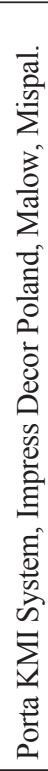 & 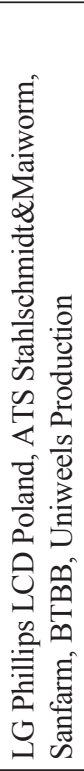 & 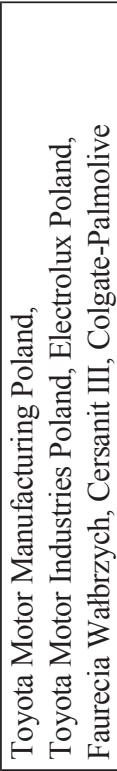 & 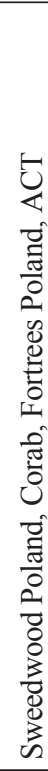 & \\
\hline$\stackrel{\infty}{\sigma}$ & ষ্ণ & $\begin{array}{l}\hat{b} \\
\dot{q}\end{array}$ & $\hat{\mathrm{o}}$ & 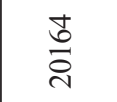 & \begin{tabular}{l}
$\widetilde{D}$ \\
\multirow{\sigma}{\sigma}{}
\end{tabular} & $\begin{array}{l}\vec{\Omega} \\
\stackrel{\Omega}{\Omega}\end{array}$ \\
\hline$\stackrel{\infty}{\sim}$ & 옹 & ஓ̊̀ & $\begin{array}{l}\stackrel{2}{\infty} \\
\infty\end{array}$ & $\begin{array}{l}m \\
\underset{0}{\infty} \\
\infty\end{array}$ & $\stackrel{n}{\mp}$ & $\begin{array}{l}\tilde{\delta} \\
\approx \\
\infty \\
\infty\end{array}$ \\
\hline $\begin{array}{l}0 \\
0 \\
0 \\
0\end{array}$ & $\frac{O}{\frac{1}{0}}$ & $\overline{8}$ & 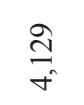 & $\begin{array}{l}n \\
\infty \\
\infty \\
n\end{array}$ & $\begin{array}{l}\infty \\
8 \\
ن\end{array}$ & $\begin{array}{l}n \\
\infty \\
0 \\
0 \\
y\end{array}$ \\
\hline$F$ & $\hat{6}$ & in & ชิ & 8 & กี & ڤิ) \\
\hline $\begin{array}{l}\bar{n} \\
\hat{n} \\
\text { ñ }\end{array}$ & 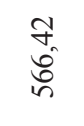 & $\begin{array}{l}n \\
\stackrel{\infty}{n} \\
\stackrel{n}{n}\end{array}$ & $\begin{array}{l}\vec{b} \\
\cdots \\
m \\
m\end{array}$ & $\begin{array}{l}\hat{n} \\
\stackrel{n}{ \pm} \\
\stackrel{ \pm}{ \pm}\end{array}$ & $\begin{array}{l}\bar{N} \\
8\end{array}$ & $\begin{array}{l}= \\
\text { శூ } \\
8\end{array}$ \\
\hline 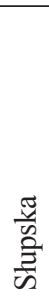 & 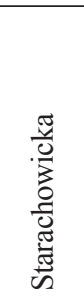 & $\begin{array}{l}\frac{\pi}{\tilde{D}} \\
\frac{\pi}{\pi} \\
\vec{\omega} \\
\tilde{n}\end{array}$ & 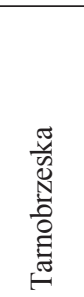 & 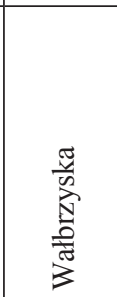 & 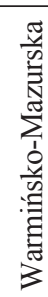 & $\begin{array}{l}\sum_{1} \\
\sum \\
\sum\end{array}$ \\
\hline$a$ & $\stackrel{\varrho}{ }$ & $=$ & $\simeq$ & 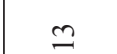 & \pm & \\
\hline
\end{tabular}


ważnych sieci dróg od 2001 r. nie pozyskała już ważnego nowego dużego inwestora, na miarę przedsiębiorstw lokalizujących swą działalność na tym terenie we wcześniejszym okresie. Podobnie prawidłowości zachodzą w czeskich strefach przemysłowych. Najważniejsze i największe inwestycje lokowane są w pobliżu istniejących bądź budowanych autostrad. Warto w tym miejscu zwrócić uwagę na ostatnie 3 bardzo ważne inwestycje na terytorium Republiki Czeskiej. Na obszarze miasta Zatec oraz w pobliskich miejscowościach utworzono strefy przemysłowe o wspólnej nazwie Triangle Zatec, które ma stać się swoistym klastrem elektronicznym, dzięki już pozyskanym inwestorom: Hitachi Home Electronics (montaż telewizorów) oraz IPS Ralpha (produkcja ekranów LCD), oba przedsiębiorstwa dają 4000 miejsc pracy. Inną ważną inwestycjąjest powstała w SP Kolin była fabryka Peugeot-Citroen-Toyota Automobile Czech. W wyścigu o pozyskanie tego inwestora startowała również Polska, jednak wszelkie proponowane przez władze lokalizacje były pozbawione m.in. odpowiedniej infrastruktury drogowej lub położone peryferyjnie wobec najprężniejszych ośrodków gospodarczych kraju, co zdecydowało ostatecznie o powstaniu fabryki w Kolinie w pobliżu Pragi, z którą to ma połączenie autostradowe (D-11 Praga-Hradec Kralove). Dzięki temu SP Kolin dała pracę 2800 osobom. Warto zwrócić uwagę, na strefę przemysłową Nosovice. Powstała ona na życzenie Hyundai, obecnie powstają kolejne w Mosnov i Holesov, gdzie proponuje się miejsca dla dostawców komponentów do fabryki w Nosovicach. Cały przygotowany obszar będzie zajmował 360 ha.

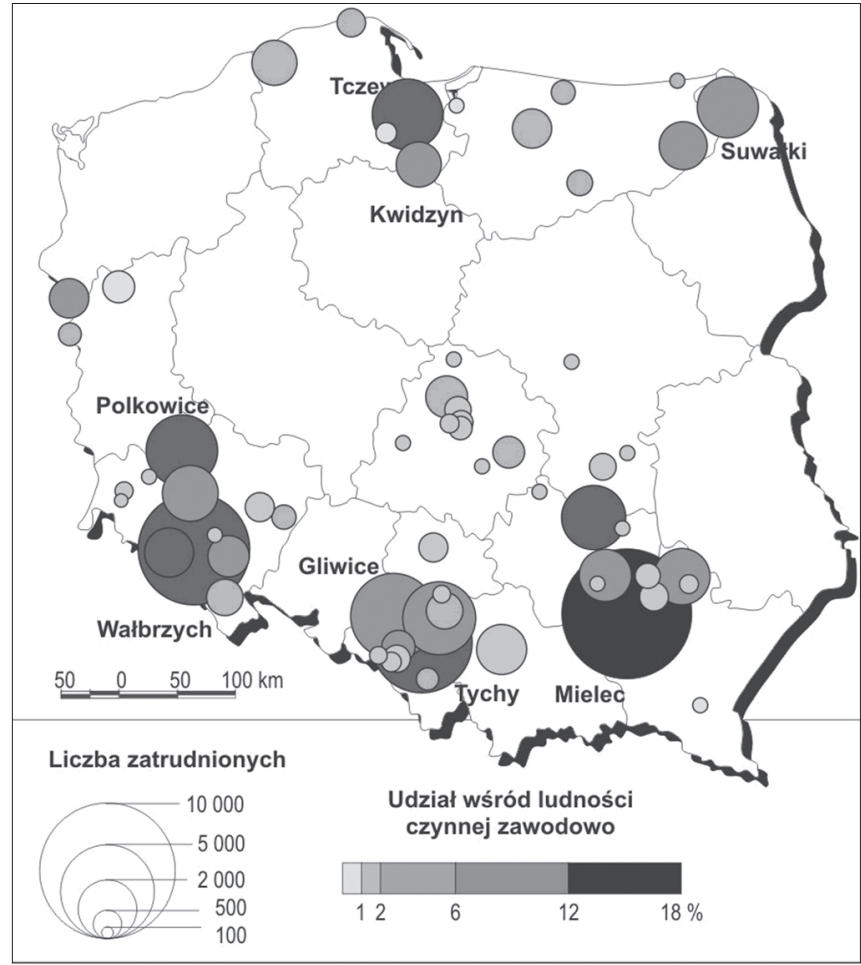

Ryc. 4. Udział pracujących w firmach na terenie SSE wśród ludności aktywnej zawodowo według powiatów

Źródło: Gwosdz, Huculak, Jarczewski, Wiedermann (2005) 


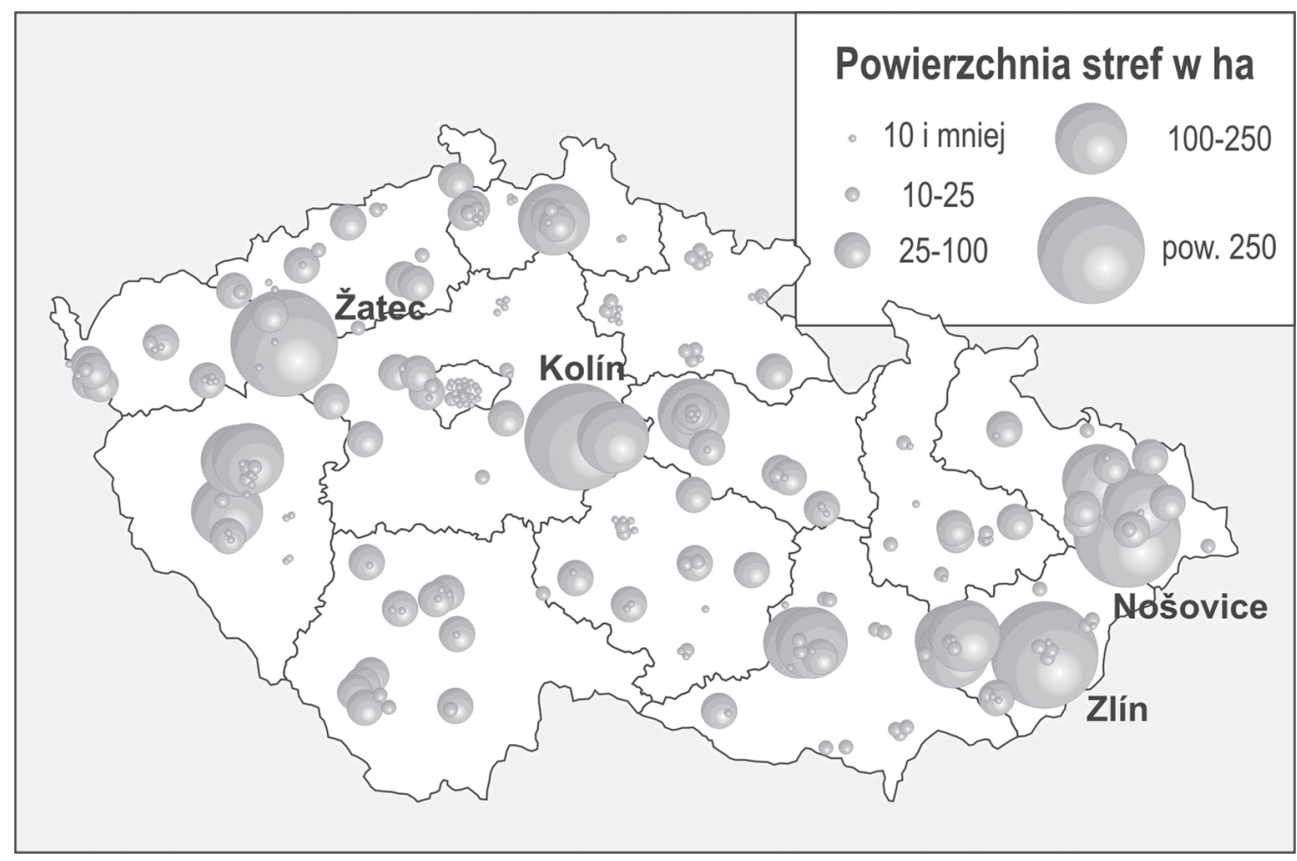

Ryc. 5. Rozmieszczenie stref przemysłowych na obszarze Czech

Źródło: opracowanie własne na podstawie danych CzechInvest 2007

\section{WNIOSKI}

Polityka tworzenia stref ekonomicznych w Polsce z perspektywy kilkunastu lat ich istnienia pokazuje, że strefy miały różny wpływ na rozwój gospodarczy regionów, na terenie których zostały ustanowione. Łącznie w pierwszym dziesięcioleciu funkcjonowania idei stref (1995-2005) powstało 14 SSE (134 lokalizacje), ponad 112 tys. miejsc pracy i zainwestowano 25,7 mld PLN (Domański, Gwosdz 2005). Przedsiębiorstwa tam zlokalizowane zajmuja powierzchnię 7,5 tys. ha, co stanowi $0,02 \%$ powierzchni kraju. W porównaniu z Republiką Czeską nie jest to wynik imponujący, gdyż tam w latach 1998-2005 powstały 92 strefy przemysłowe, w nich zlokalizowało się 350 przedsiębiorstw typu greenfield, dały one ponad 50 tys. nowych miejsc pracy i zajęły $78 \%$ powierzchni przeznaczonych na inwestycje, co stanowi 0,13\% powierzchni kraju (dane CzechInvest).

Rozpatrując warunki konkurencyjności wewnętrznej poszczególnych regionów, a także zewnętrznej Polski, ważnym elementem ją kształtującym są specjalne strefy ekonomiczne. Analizując sukces poszczególnych stref, dochodzimy do wniosku, że za jeden z istotnych czynników należy uznać czas ich powstania. W przypadku SSE Euro-Park Mielec mieliśmy niewątpliwie do czynienia z sukcesem wynikającym z braku szerokiej konkurencji w pierwszym okresie jej funkcjonowania. To umożliwiło pozyskanie dużych kluczowych dla miasta inwestorów. Wraz z rosnącą liczbą obszarów objętych przywilejami coraz mniej inwestycji trafiało do miejsc peryferyjnych bądź mniej atrakcyjnych do prowadzenia działalności prze- 
mysłowej. Tworzenie stref w obszarach o dobrych uwarunkowaniach rozwoju przemysłu wpływało natomiast na wzrost atrakcyjności inwestycyjnej kraju.

Dzisiejsze rozwiązania w tym zakresie odbiegają istotnie od założeń pierwotnych idei stref ekonomicznych, gdyż tworzone na życzenie inwestorów strefy obejmują miejsca najatrakcyjniejsze. Doprowadziło to do sytuacji, w której dysproporcje pomiędzy obszarami peryferyjnymi i centrami rozwoju gospodarczego są większe. Niemniej z punktu widzenia polityki gospodarczej kraju Polska staje się coraz bardziej konkurencyjna. Patrząc na obecny napływ kluczowych inwestycji do krajów Europy Środkowej, nie powtarzają się bowiem sytuacje końca lat 90. i początku obecnej dekady XXI w., kiedy to najważniejsze inwestycje trafiały do Czech czy na Słowację (Peugeot-Citroen-Toyota, VW, Kia czy Hyundai), gdyż oferty składane tym inwestorom ze strony Polski dotyczyły zazwyczaj mało atrakcyjnych ośrodków miejskich, często położonych peryferyjnie, które nie miały możliwości konkurowania z okolicami Pragi, Bratysławy, Ostrawy, Trnawy czy Żyliny.

\section{Literatura}

Bagdziński S., Maik W., 1994, Determinants of regional and spatial policy in the period of system transformation, [w:] R. Domański, E. Judge, red., Changes in the regional economy in the period of system transformation, PWN, Warszawa, s. 55-69

Budzowski K., Świętowiec J., 1997, Przesłanki tworzenia i warunki funkcjonowania stref uprzywilejowanych, „Zeszyty Naukowe Akademii Ekonomicznej w Krakowie”, 501, s. 75-86

Guangwen M., 2003, The theory and practice of free economics Jones: a case study of Tianjin, People's republic of China, Combined Faculties for the Natural Scienes and for Mathematics of RuprechtKarls University of Heidelberg, Germany, Ph.D. dissertation

Domański B., Gwosdz K. red., 2005, Dziesięć lat doświadczeń pierwszej polskiej specjalnej strefy ekonomicznej. Mielec 1995-2005, Instytut Geografii i Gospodarki Przestrzennej Uniwersytetu Jagiellońskiego w Krakowie, Agencja Rozwoju Przemysłu S.A. Oddział w Mielcu

Gwosdz K., Huculak M., Jarczewski W., Wiedermann K., 2005, Specjalne strefy ekonomiczne w Polsce. Założenia a praktyka, [w:] B. Domański, K. Gwosdz, red., Dziesięć lat doświadczeń pierwszej polskiej specjalnej strefy ekonomicznej, Mielec 1995-2005, Instytut Geografii i Gospodarki Przestrzennej Uniwersytetu Jagiellońskiego w Krakowie, Agencja Rozwoju Przemysłu S.A. Oddział w Mielcu

Kryńska E. red., 2000, Polskie Specjalne Strefy Ekonomiczne - zamierzenia i efekty, Europejski Instytut Rozwoju Regionalnego i Lokalnego UW, Warszawa

Kukliński A., 1991, Restrukturyzacja regionów jako problem wspótpracy europejskiej, [w:] A. Kukliński, B. Jałowiecki, red., Restrukturyzacja regionów jako problem wspótpracy europejskiej, Uniwersytet Warszawski, t. 1. Studia Regionalne i Lokalne, 1 (34), s. 319-329

Kuliś S., 2001, Przestrzenne zróżnicowanie aktywności inwestycyjnej w specjalnych strefach ekonomicznych $w$ Polsce, maszynopis w Instytucie Geografii i Gospodarki Przestrzennej UJ

Raport Ministerstwa Gospodarki, 2008, Informacja o realizacji ustawy o specjalnych strefach ekonomicznych - stan na 31 grudnia 2007

Rozporządzenie Rady Ministrów z dnia 13 października 2006 r. w sprawie ustalenia mapy pomocy regionalnej (Dz. U. Nr 190. poz. 1402)

Smith D.M., 1966, A theoretical framework for geographical studies of industrial location, „Economic Geography", s. 95-113

Ustawa z dnia 20 października 1994 r. o specjalnych strefach ekonomicznych (Dz. U. Nr 123, poz. 600 )

Ustawa z dnia 16 listopada 2000 r. o zmianie ustawy o specjalnych strefach ekonomicznych i zmianie niektórych ustaw (Dz. U. Nr 117, poz. 1228) 
Ustawa z dnia 2 października 2003 r. o zmianie ustawy o specjalnych strefach ekonomicznych i niektórych ustaw (Dz. U. Nr 188, poz. 1840, z późn. zm.)

Ustawa z dnia 23 czerwca 2006 r. o zmianie ustawy o specjalnych strefach ekonomicznych oraz niektórych ustaw (Dz. U. Nr 141, poz. 997)

\section{Special economic zones and industrial zones in the shaping of regional economic development on the example of Poland and the Czech Republic}

The aim of the present work is to show how the changing approach to special economic zones in Poland influenced the competitiveness of Polish regions, both on the internal and external scale. In the case of external conditioning, a comparative analysis of competitiveness of Polish regions against the Czech regions was conducted.

In the examination of the internal- and external competitiveness conditions of particular Polish regions, an important element that shapes it is the existence of special economic zones. Their location positively affects the competitiveness of the given region, due to lower costs of functioning for the subjects active in the area. According to the original assumptions, creation of the zones was designed as a privilege for problem areas, e.g. characterized by high unemployment or low industrialization.

Today's solutions in this aspect considerably depart from the original assumptions of the idea of special zones, as - created when demanded by the investors - the zones include the most attractive regions. This has led to a situation when disproportion between peripheral and central areas of economic development is increasing. On the other hand, from the point of view of the state's economic policy, Poland becomes more competitive. When observing the current inflow of crucial investments into the Central-European countries, we do not see situations typical of the 1990s and the first decade of the $21^{\text {st }}$ century, when the most important investments were aimed at the Czech Republic or Slovakia (PeugeotCitroen-Toyota, VW, Kia or Hyundai), since the offers made by Poland to these investors usually concerned relatively unattractive locations, often peripheral, which could not compete with the areas of Prague, Bratislava, Ostrava, Trnava or Zilina. 